Nataliia Vasylyshyna,

PhD (Candidate of Pedagogical Sciences), associate professor, Educational Scientific Institute of International Relations, National Aviation University,

4, Vidradnyi Avenue, building 7, Kyiv, Ukraine

\title{
PRIORITIES OF TOURISM HIGHER EDUCATION ADVANCEMENT AND ACQUIRING FOREIGN LANGUAGE COMMUNICATION ABILITIES AS A COMPONENT OF TRAINING SPECIALISTS IN UKRAINE AND TURKEY
}

The paper presents the current state, strategies and peculiarities of tourism higher education in Ukraine and Turkey. The necessity of adjusting educational standards to rapidly developing socio-economic processes is emphasised. Special attention is paid to the role of foreign language communicative competence as a necessary component of training specialists majoring in tourism.

Keywords: training, tourism education, English for specific purposes, foreign language communicative competence, skills, specialists, priorities, strategies, degrees, programs.

Introduction. The dramatic socio-economic reforms that began to be embodied in Ukraine after the signing of the "Agreement on Association between Ukraine, on the one hand, and the European Union, the European Community of Atomic Energy and their Member States, on the other hand," have the significant influence on all spheres of the national economy, including higher education $[9 ; 13]$.

It is especially important for the training of specialists who are supposed to promote Ukraine's image in the world, to push forward the revival of the national and regional economy. Tourism corresponds to all the criteria of "the catalyst of economic recovery" $[9 ; 13]$.

It is worth mentioning that tourism sector has a structure that is different from the other sectorsof economy, because at its every level labour force continuously deals with consumers. Besides, it is a must for students who get tourism education to understand the international nature of tourism products and markets.

According to the strategic success factors of tourist destinations and regions, better management of service organisations, desirable behaviour of customers in market dynamics is provided by tourist service personnel that should be managed efficiently and have to possess foreign language skills as a compulsory component of their professional competence [3].

We must admit that English is indisputably the primary language of global trade and commerce, and tourism, since in many countries, most tourism authorities and other officials in contact with the public speak English to interact and communicate with tourists and immigrants. Among a great number of vocational areas that make up the sphere of English for specific purposes, English for tourism is one of the most attractive [7].

After all, tourism, tourist activity provides service sector with jobs, attracts investments in the region and helps to improve the country's image in the world. This review of the issue demonstrates that much attention should be paid to the training of young specialists in tour- ism and recreation spheres in countries with developing economies. We have to point out that Ukraine and Turkey have the significant potential for tourism development.

On balance, all the above-mentioned indicate the actuality of the current pedagogical research.

The paper is aimed at outlining the main research results concerning the basic features, peculiarities, tendencies, impacts, and effects of further training of specialists at tourism higher educational institutions of Ukraine and Turkey under current conditions.

Consequently, with the reference to the aim of the paper, the two tasks were set up at the outset of our investigation: firstly, to examine the state of higher educational systems in the area of tourism in Ukraine and Turkey, and, secondly, to define the factors, principles and priorities of their improvement.

The current pedagogical study involved the use of theoretical methods, systemic method; analysis, synthesis, inductive and deductive methods that helped us focus on the certain peculiarities of higher education systems in the area of tourism in Ukraine and Turkey.

Obviously, tourism is already a field of science and an interdisciplinary science that investigates and researches phenomena related to tourism field by means of scientific methodology that aims to establish cause-effect relations. Therefore, we cannot talk about a single approach or methodology applied in studies carried out in the field of tourism.

Besides, tourism used to be a part of social science and benefited from all the qualitative and quantitative methods the social sciences traditionally employ. The number of research works in the sphere of tourism is increasing at both national and international levels, which leads to rapid increase in the amount of tourism programmes offered by faculty departments, and to the emergence of academic institutions where tourism is studied as a major branch of knowledge [11].

Thus, the listed above factors resulted in the creation of a great number of complex and variable structures and 
forms of tourism higher education, which brings out the question about the content and differences among them by means of analysing each structure's content and its compliance with the requirement of a certain industry [11].

The issues of tourism higher education in Ukraine and Turkey. Ukraine joined the Bologna Process in 2005. Key developments since then include: approval of an action plan on Quality Assurance in higher education; amendments to the law on higher education, according to the Bologna principles and recommendations; inclusion of Ukraine as a governmental member into the European Quality Assurance Register; further developed National Qualification Framework [10; 11].

Consequently, significant progress has been achieved in three strategic areas of the Bologna Process: implementation of a two-cycle system; implementation of quality assurance in the field of higher education; recognition of diplomas and previous studies. The general trend towards decentralisation is aimed at delegating a certain amount of authority and responsibilities to the higher educational institutions[6].

According to the Ukrainian constitution, access to free education is granted to all citizens. Complete general secondary education is compulsory in the state schools which constitute the overwhelming majority. Free higher education in state and communal educational establishments is provided on a competitive basis. There are also a small number of accredited private secondary and higher educational institutions [5].

The Ukrainian higher education system comprises higher educational establishments, scientific and methodological facilities under federal, municipal and selfgoverning bodies in charge of education. The organisation of higher education in Ukraine is built up in accordance with the structure of education of the world's developed countries, as defined by UNESCO and the UN [13].

The Constitution of Ukraine, Law on Education, Law on Higher Education, decrees, and regulations of the President and Cabinet of Ministers of Ukraine define the main directions of Ukrainian State policy for higher education. The Law on Higher Education regulates the professional training of Ukrainian citizens and sets the legal, organisational, and financial basis for the national higher education system [8].

The Verkhovna Rada (Parliament) of Ukraine provides a general outline of the State policy in the field of higher education, based on the following principles: merit-based access to higher education for all Ukrainian citizens; independence of higher education institutions from political parties and/or public and religious organisations; pursuit of the international integration of Ukrainian higher education, while preserving the achievements and traditions of the national system; state support for training specialists in fundamental and applied research; raising the educational level of Ukrainian citizens and widening the prospects for higher and other forms of postsecondary education; availability of student loans; granting special rights to students at higher education institu- tions; adequate support for the education of the disabled; the modernisation of the Ukrainian higher education system [8].

The principles and factors of tourism higher education democratisation include: new market-oriented and competitive social and economic media; distinction between education and professional training in higher education; growing differentiation of content among the different educational and qualification levels; introduction of objective evaluation and monitoring of results.

Moreover, the challenges of the twenty-first century call for a radical modernisation of the system of education and guaranteed self-realisation of every person based on lifelong education [8].

At present, the priorities of the Ukrainian educational policy include: national education, language education, equal access to education, quality of education, lifelong learning, funding of education, scientific research, academic staff, social security, international co-operation. Further in our research we are aimed at defining each of the mentioned above priorities in the higher education that can be directly applied to tourism area.

The first priority is national education. Ukrainian education is humanistic-oriented and based on the cultural, historical, and spiritual heritage of the nation. The national education system conveys principles of humanism, democracy, cultural diversity, consistency, and tolerance [8].

The second priority is language education. The system of education should continue to ensure knowledge of both native and foreign languages. Education should address the right of national minorities to be educated in their native language and safeguard their culture with State support and protection [8].

The third priority is equal access to education. The State guarantees equal and merit-based access to education of all citizens, irrespective of their social origin, status, religion, place of residence, or state of health [8].

The fourth priority is quality of education. Modernisation of the system of education should take place in accordance with the latest achievements in all fields of studies [8].

The fifth priority is lifelong learning. The implementation of State policy in the field of continuous education takes into account international and domestic trends of social and cultural development [8].

The sixth priority is funding of education as a priority of State planning of expenditures. Various forms of financial support include direct budget financing of tuition fees, State scholarships, various grants, and municipal loans [8].

The seventh priority is scientific research. Ukrainian higher educational institutions have always considered student participation in research as a basic, necessary element of their training [8].

The eighth priority is academic staff. In order to provide training and development of teaching and research 
staff, the State provides a sound legal basis for professional activities [8].

The ninth priority is social security. Ukraine strives to raise the prestige and social status of teaching staff, research staff, and students. Students receive health care services free of charge, public transportation discounts, and educational loans.

The tenth priority is international co-operation. In the context of globalisation and creation of regional education areas, the State promotes the entry of Ukrainian education into the world educational market and fosters international co-operation between Ukrainian stakeholders and international organisations. The cooperation between Ukrainian educational institutions and various intergovernmental and non-governmental international organizations - UNESCO, UNICEF, the European Union, the Council of Europe - is strengthening [8].

The main trends of Ukrainian international cooperation in the field of education and science include joint research, co-operation with foundations, organisation of scientific conferences, seminars and symposia, educational and scientific exchange, and research publications. The Ukrainian educational system is open to collaboration with various international institutions and organisations with the purpose of the development of mutual understanding and tolerance and contribution to the European Project, while preserving Ukraine's national heritage [8].

In Ukraine, tourism studies are mostly chosen by individuals who want careers associated with managing and planning tours and related events for people. Topics covered may include the business of tourism, sales, marketing strategies, development, planning, and tour design. Bachelor's degree in tourism is concerned with the management of different organisations related to tourism, e.g. resorts, hotels, attractions, etc. It is intended for students who are creative, interested in languages and serviceminded [9].Master's degree gives future professionals the opportunity to either further their understanding of a particular question or develop in a completely different way using skills they have gained from their previous undergraduate degree [9].

The point we have to stress is that the university sector in Ukraine and Turkey is still changing at an increasing rate. Teaching now has a higher priority in most of today's universities. Twenty years ago, public funding paid for virtually $100 \%$ of costs of the tertiary sector, but today that is very far from being realistic. Turkey, for example, is now heading towards $30 \%$ of university funding from the public purse. The bulk of the missing funding comes from student fees. That is having profound effects on both students and university teaching. That changed the nature of universities and the university mission: they became corporatized and competitive for markets $[9 ; 13]$.

Now that students have to pay higher fees, they will be likely to demand programmes that are taught well and will enhance their employment prospects. Some of them search for appropriate programmes, while others, using the logic that education is a commodity to be bought, feel that having paid for a degree they are entitled to be awarded one. The pressures on teaching staff are complex: they are expected to teach in a student-friendly manner, but the above-mentioned circumstances may result in the lowering of teaching standards.

On the other hand, Ukraine has one more contradiction that is related to the problem that higher educational establishments usually focus solely on the educational process. Moreover, the scientific activity of teachers has remained "derivative" of the educational process [13]. As a manifestation of this problem - scientific publications of Ukrainian university teachers have low citation rating. Also, the amount of author's publications in journals indexed in the leading international scientific and metric databases, such as Web of Science, Scopus, and others are insignificant [9].

At the level of higher education in Turkey, the first formal programme on tourism was offered in 1965, when the Commerce Teachers School in Ankara was renamed as "Commerce and Tourism Teachers School". The main aim of the school was to train teachers for secondary-level commerce and tourism schools [14].

At the postgraduate level, the first master's programme in tourism was offered in 1969 at Istanbul University's Institute of Economics, Geography, and Tourism; and the first doctoral programmes were offered at Bogazici and Ege Universities in 1975-1976 [14].

There emerged the shortage of qualified staff to fill lower, middle, and senior positions in tourism organisations. This led to a further increase in demand for degree programmes in the field. At the same time, 25 state and 21 private universities were founded between 1992 and 2004 to expand higher education further [14].

Most of these new universities, as well as the existing ones, started offering programmes ranging from bachelor to postgraduate degree programmes in tourism and hospitality management. Along with some positive and promising outcomes, the opening of such a great number of programmes has resulted in a number of problems and challenges [9].

Turkey has experienced rapid growth in tourism since the early 1980s. In 1982, a special law was enacted to encourage the development of tourism, with the aim of ensuring that the necessary arrangements were in place to regulate and develop a dynamic structure for the tourism sector. Between 1985 and 1990, investors received US\$422 million of cash incentives and US\$1.1 billion of medium- and long-term bank credits. They also used their own resources, valued at US\$1.5 billion, and most of these resources were invested in the hotel industry [10].

The growth of the tourism industry has not been supported with sound strategies and strategic plans. Tourism in Turkey has been facing serious problems for many years, including seasonality, low hotel occupancy rates, a high dependency on tour operators, transportation difficulties, inadequate infrastructure, poor service quality, a 
lack of qualified staff, a lack of sound marketing programmes, a high percentage of lower-income tourists, and the effects of national and global crises [10].

Similarly, the number of students reached $19,437,566$ in 2005 , compared to 1923 when there were 364,428 , including 2,194 students of higher educational institutions. The number of teachers has also increased to 710,900 , including 77,065 academic staff of higher educational institutions, from only 12,573, including 307 academic staff of higher educational institutions in 1923. The literacy rate was lower than $10 \%$ in the early years of the newly-established Republic.

Under these circumstances, education faced the radical political, economical, judicial and cultural changes that had a certain impact on it. As a result, a number of changes were made in the process and content of education. Additionally, significant improvements were achieved in both the quality of education and in the distribution of educational opportunities throughout the country [10].

As of 2011-2012 academic year in Turkey, four-year undergraduate tourism education programmes were represented at 13 tourism faculties, 14 tourism management departments and 33 hotel and tourism management schools. Thus, tourism higher education in Turkey is rather varied with different curriculums and structures offered by different universities, which makes accreditation procedures harder. Almost all the vocational schools are offering tourism programmes $(80 \%)$, which is different from the situation at higher educational institutions providing 4-year undergraduate training $[10 ; 11]$.

Despite the fact that high overall performance of Turkish education and the efforts made in this field since the declaration of the Republic are considered to be satisfactory, there are some problems associated with providing educational services. Some of them are related directly to the Ministry of National Education and some are related to the policies of the state and successive governments. The issues, which Turkey faces in the field of education stem mainly from the rapid increase in population, migration from rural to urban areas, and budget restrictions [3].

Consequently, a considerable part of the present projects and work is directed towards the solution of such challenges as: crowded classrooms; unsatisfactory schooling rates; waste of resources and time caused by failure or repetition of the grade; double shift education; integrated classrooms especially in rural areas; lack of equipment; lack of finance; problems related to the training, balanced distribution, economic conditions, social status and inservice training of teachers; need for review of the curricula and the educational material according to the changing and varying educational needs of society $[3 ; 2]$.

It is worth mentioning that nowadays tourism education in Turkeyis handled under two titles: formal and nonformal education. Formal education is the regular education for the same level of individuals at certain age group and with programmes prepared according to an objective under the umbrella of school. Formal education includes pre-school education, primary school, elementary and higher education institutions [2].

Non-formal education provides services, such as: to prepare continuous education possibility for the students to complete their missing parts of education; to provide the educational possibility for the students facilitating their adaptation to technological, economic, social and cultural developments; with the economic development direction, and according to the employment policy, create possibilities for getting a job; to provide healthy nutrition and lifestyle[2].

Tourism educational programmes facilitate students' acquisition of tourism-related abilities and skills, provide them with certificates on successful completion of the training course and get them involved into practice in the field. With the purpose of improvement, Tourism Education Centres were founded by the Ministry of Tourism in order to prepare qualified staff for the tourism sector $[2 ; 14]$.

In addition, universities running tourist guide education programmes are already conducting classes in English, German and French languages. Therefore, the Ministry of Culture and Tourism should establish the necessary cooperation and coordination with the Ministry of Education for increasing the number of students enrolled into the tourism-related and foreign language faculties [9].

Thus, implementation of the strategy of tourism education advancement requires taking corresponding measures. Firstly, arrangements should be made for universities running departments on tourism business administration to offer postgraduate studies with or without a graduation thesis for university graduates of relevant programmes who have good command of at least one foreign language. Secondly, education for tourist guides should be given at Bachelor's degree and all associate degree programmes should be abandoned. Thirdly, the gradual implementation of Master's degree programmes at schools offering only Bachelor's degree in tourist guide education will facilitate enhancement of their training specialists in this field $[2 ; 3 ; 14]$.

Acquiring skills of English for specific purposes. Firstly, the word "specific" in the term "English for specific purposes" was used to refer to the language varieties typical of a professional activity.

Further on, T. Hutchinson and A. Waters explained that English for specific purposes is not the matter of teaching specialised varieties of English. As any other form of language teaching, it should be based, first of all, on principles of effective and efficient learning [7].

Secondly, P. Robinson describes English for specific purposes as a type of English Language Teaching and defines it as goal-oriented language learning [12].

Thirdly, T. Hutchinson and A. Waters emphasise that English for specific purposes is an approach, not a product, that is, language learning is of importance, not its use. They drew attention to a "learning-centred approach", in which, from their point of view, all decisions related to 
content and methods are based on the learner's reason for learning [7].

Finally, T. Dudley-Evans divided characteristic features of English for specific purposes in two groups according its "absolute" and "variable" attributes [4]. Concerning the absolute characteristics, according to T. Dudley-Evans, English for specific purposes:

- is defined to meet specific needs of the learner;

- makes use of the basic methodology and activities of the discipline it serves;

- is centred on the language (grammar, vocabulary), skills, discourse and genres appropriate to these activities; plines;

may be related to or designed for specific disci-

may use in specific teaching situations a methodology that is different from the one applied in general English teaching;

- is likely to be designed for adult learners, either at a tertiary level institution or in a professional work situation and is generally designed for intermediate or advanced students [4].

As a result, we can conclude that foreign language communicative competence in the area of tourism is considered as an intrinsic part of qualified tourism training. In our research, it is defined as the progressive acquisition of the ability to use a language in order to achieve communicative purpose by future specialists in tourism sphere. Besides, foreign language communicative competence:

- involves the exchange of ideas between two or more persons sharing the same symbolic system;

- is applied to both spoken and written language;

- is context-specific based on the situation, the role of the participants and the appropriate choices of register and style (for example: the variation of language used by persons of different jobs or professions can be either formal or informal, the use of jargon or slang may or may not be appropriate);

\section{ЛІТЕРАТУРА}

1. Association for Tourism in Higher Education [Електронний peсурс]. - Режим доступу : https://www.athe.org.uk/.

2. Biggs J. Teaching for quality learning at university/ J.Biggs. - Buckingham : The Open University, 2003. $-357 \mathrm{p}$.

3. Burkart J. Tourism: Past, Present and Future/ J. Burkart, S. Medlik. - L. : Heinemann, 1981. - P. 19-28.

4. Dudley-Evans A. Developments in English for Specific Purposes: A Multi-Disciplinary Approach / A. Dudley-Evans, M. Jo St. John. - Cambridge : Cambridge University Press, 1998. - 301 p.

\section{Режим}

5. Educationin Ukraine [Електронний ресурс]. доступу://www.dnu.dp.ua/en/education_in_ukraine.
- represents a shift in focus from the grammatical to the communicative properties of the language, the functions of a language and the process of discourse;

- requires the mastery of the production and comprehension of communicative acts or speech acts that are relevant to the needs of the learner [12].

Conclusions. Based on the above-mentioned discussion and evaluations, a number of conclusions can be drawn. Nowadays there have been some positive progress and good results in the sphere of tourism higher education in Ukraine and Turkey that can be presented by the next principles and factors of tourism higher education: new market-oriented and competitive social and economic media; distinction between education and professional training in higher education; growing differentiation of content among the different educational and qualification levels; introduction of objective evaluation and monitoring of results.

The priorities of the educational policy in both countries were exemplified by: national education, language education, equal access to education, quality of education, lifelong learning, funding of education, scientific research, academic staff, social security, international cooperation.

However, there are several common challenges and problems at the Bachelor and Master's levels. The main difficulties that tourism programmes face include a lack of qualified academic staff, improperly designed curricula, limited opportunities of practical training for students, and keeping qualified graduates in the industry.

If Ukraine and Turkey are to gain more from tourism in the long run, it is essential to improve the standards of tourism higher education. A number of recommendations can be made. Thus, further field of investigation in tourism higher education is supposed to include the following issues: revising the curriculum; certifying teaching staff, auditing and certifying tourism programmes; providing more funding; and finally, establishing collaboration between tourism programmes and industry partners, and international universities.

6. Higher education in Ukraine [Електронний peсурс]. - Режим доступу : http://www.tempus.org.ua.

7. Hutchinson T. English for Specific purposes : a Learning-Centered Approach / T. Hutchinson, A. Waters. - Cambridge : Cambridge University Press, 1987. - 188 p.

8. Kremen V. Higher Education in Ukraine / V. Kremen, S. Nikolaienko. - Bucharest : UNESCO-CEPES, 2006. -99 p.

9. Ministry of Tourism [Електронний pecypc]. Режим доступу : http://www.tatnews.org/ministry-oftourism-and-sports/.

10. Okumus F., Yagci O. Tourism Higher Education in Turkey [Електронний pecypc] / F. Okumus, O. Yagci //Journal of Teaching in Travel \&Tourism. - 2006. - 5(1- 
2). - 89-16. - Режим доступу : https://www.researchgate.net/publication/254379277_Tou rism_Higher_Education_in_Turkey.

11. Pirnar I. Tourism Education Universities in Turkey : Comparison of Different Structures and Related Effects on Education [Електронний ресурс] / I. Pirnar // Social and Behavioural Sciences. - 2013. - 116. - Режим доступу : www.sciencedirect.com.

\section{REFERENCES}

1. Association for tourism in higher education. Retrieved from:https://www.athe.org.uk/[in English].

2. Biggs, J. (2003).Teaching for quality learning at university. Buckingham: The Open University [in English].

3. Burkart, J.,\& Medlik, S. (1981). Tourism: past, present and future. L.: Heinemann [in English].

4. Dudley-Evans, A. (1998). Developments in English for specific purposes: A multi-disciplinary approach. Cambridge: Cambridge University Press[in English].

5. Education in Ukraine. Retrieved from: http://www.dnu.dp.ua/en/education_in_ukraine [in English].

6. Higher education in Ukraine. Retrieved from: www.tempus.org.ua[in English].

7. Hutchinson, T.,\& Waters, A. (1987).English for specific purposes: A learning-centred approach. Cambridge: Cambridge University Press [in English].

8. Kremen, V., \& Nikolaienko, S. (2006) Higher Education in Ukraine. Bucharest: UNESCO-CEPES [in English].
12. Robinson P. ESP today : A Practitioners' Guide /P. Robinson. - New York : Prentice Hall International, 1991. $-146 \mathrm{p}$.

13. The Council of Higher Education [Електронний pecypc]. - Режим доступу : www.yok.gov.tr.

14. Yagci Ö. Tourism education in Turkey, basic problems of employment and solution suggestions / Ö.Yagci // Journal of Commerce and Tourism Education Faculty. - 2001. - № 4 (1). - 23-39.

9. Ministry of tourism. (2002). Retrieved from: http://www.tatnews.org/ministry-of-tourism-and-sports/ [in English].

10. Okumus, F., \&Yagci, O. (2006). Tourism higher education in Turkey. Journal of teaching in travel \& tourism, 5(1-2), 89-116. Retrieved from: https://www.researchgate.net/publication/254379277_Tou rism_Higher_Education_in_Turkey [in English].

11. Pirnar, I. (2013). Tourism education universities in Turkey: Comparison of different structures and related effects on education. Social and behavioural sciences, 116, 5070-5074.Retrieved from: www.sciencedirect.com [in English].

12. Robinson, P. (1991).ESP today: A practitioners' guide. New York: Prentice Hall International [in English].

13. The council of higher education (2004). Retrieved from: www.yok.gov.tr [in English].

14. Yagci, Ö. (2001). Tourism education in Turkey, basic problems of employment and solution suggestions. Journal of commerce and tourism education faculty, 4(1), 23-39 [in English].

\section{Наталія Максимівна Василишина, кандидат педагогічних наук, дочент, Навчально-науковий інститут Міжнародних відносин, Наиіональний авіаційний університет, проспект Відрадний 4, корпус 7, м. Київ, Украӥна}

\section{ПРІОРИТЕТИ ВДОСКОНАЛЕННЯ ВИЩОЇ ОСВІТИ СФЕРИ ТУРИЗМУ ТА ФОРМУВАННЯ ІНШОМОВНИХ КОМУНІКАТИВНИХ ВМІНЬ ЯК Ї̈̈ НЕВІД'ЄМНА ЧАСТИНА ПІДГОТОВКИ ФАХІВЦІВ В УКРАЇНІ ТА ТУРЕЧЧИНІ}

У статті розглядається сучасний стан, проблеми, стратегії і особливості вищої освіти туризму в Україні і Туреччині. Підготовка фахівців сфери туризму повинна відповідати сучасним реформам і соціальноекономічним процесам, які стрімко розвиваються. Тому мета дослідження полягала в аналізі особливостей, тенденцій, пріоритетів удосконалення та оновлення підготовки фахівців сфери туризму у вищих навчальних закладах України і Туреччини. Відповідно до поставленої мети дослідження, були виділені два завдання: поперше, вивчити стан систем вищої освіти в сфері туризму в Україні та Туреччині, i, по-друге, визначити чинники, принципи та пріоритети ії вдосконалення. Наукова робота грунтувалася на теоретичних методах, зокрема: системний метод, аналіз, синтез, індуктивний та дедуктивний методи, які сприяли акцентуванню уваги на конкретних принципах, пріоритетах та особливостях систем вищої освіти в сфері туризму в Україні та Туреччині. На сьогодні, за результатами нашого наукового пошуку, пріоритетами удосконалення освітньої політики в обох країнах є: розвиток і впровадження національної освіти, поглиблення філологічної освіти (англійська мова), доступність отримання освіти та рівність у правах, система менеджменту якості освіти, безперервність освіти, фінансування освіти, розробка наукових досліджень, підвищення кваліфікації академічного персоналу, соціальне забезпечення, а також міжнародне співробітництво вищих навчальних закладах сфери туризму. До того ж, слід акцентувати увагу, що іншомовна професійна комунікативна компетентність майбутніх фахівців галузі туризму розглядається як невід’ємна частина підготовки у вищих навчальних закладах України і Туреччини. У 
рамках нашого дослідження, іншомовна професійна комунікативна компетентність майбутніх фахівців галузі туризму, як один із важливих пріоритетів освітньої політики, розглядається як поступове оволодіння вміннями використовувати англійську мову для досягнення комунікативних професійних цілей майбутніми фахівцями в сфері туризму. Результати наукового пошуку доводять, що в наш час були досягнуті значні позитивні результати діяльності вищих навчальних закладів сфери туризму в обох країнах. Однак, існує кілька загальних завдань $\mathrm{i}$ проблем на освітньо-кваліфікаційних рівнях «Бакалавр» і «Магістр» в Україні та Туреччині. Як наслідок, наступний вектор досліджень в галузі туризму вищої освіти може бути спрямований на аудит і сертифікацію навчальних програм, шляхи забезпечення фінансування, а також налагодження співпраці між туристичними програмами, галузевими партнерами та міжнародними університетами.

Ключові слова: професійна освіта, туристична освіта, англійська мова за професійним спрямуванням, іншомовна комунікативна компетентність, навички, фахівці, пріоритети, стратегії, ступені, програми.

Наталья Максимовна Василишина, кандидат педагогических наук, доиент,

Учебно-научный институт Международных отношений, Национальный авиационный университет, проспект Отрадный 4, корпус 7, г. Киев, Украина.

\section{ПРИОРИТЕТЫ СОВЕРШЕНСТВОВАНИЯ ВЫСШЕГО ОБРАЗОВАНИЯ СФЕРЫ ТУРИЗМА И ФОРМИРОВАНИЕ ИНОЯЗЫЧНЫХ КОММУНИКАТИВНЫХ УМЕНИЙ КАК НЕОТЬЕМЛЕМАЯ ЧАСТЬ ПОДГОТОВКИ СПЕЦИАЛИСТОВ В УКРАИНЕ И ТУРЦИИ}

В статье рассматривается современное состояние, проблемы, стратегии и особенности высшего образования туризма в Украине и Турции. Подготовка специалистов сферы туризма должна соответствовать современным реформам и социально-экономическим процессам, которые развиваются стремительно. Поэтому цель исследования заключалась в анализе особенностей, тенденций, приоритетов усовершенствования и обновления подготовки специалистов сферы туризма в высших учебных заведениях Украины и Турции. Согласно поставленной цели исследования, были выделены две задачи: во-первых, изучить состояние систем высшего образования в сфере туризма в Украине и Турции, и, во-вторых, определить факторы, принципы и приоритеты его совершенствования. Научная работа основывалась на теоретических методах, в частности: системный метод, анализ, синтез, индуктивный и дедуктивный методы, которые способствовали акцентированию внимания на конкретных принципах, приоритетах и особенностях систем высшего образования в сфере туризма в Украине и Турции. На сегодняшний день, по результатам нашего научного поиска, приоритетами усовершенствования образовательной политики в обеих странах являются: развитие и внедрение национального образования, углубление филологического образования (английский язык), доступность получения образования и равенство в правах, система менеджмента качества образования, непрерывность образования, финансирование образования, разработка научных исследований, повышение квалификации академического персонала, социальное обеспечение, а также международное сотрудничество в высших учебных заведениях сферы туризма. К тому же, следует акцентировать внимание, что иноязычная профессиональная коммуникативная компетентность будущих специалистов отрасли туризма рассматривается как неотъемлемая часть подготовки в высших учебных заведениях Украины и Турции. В рамках нашего исследования, иноязычная профессиональная коммуникативная компетентность будущих специалистов отрасли туризма, как один из важных приоритетов образовательной политики, рассматривается как постепенное приобретение способностей использовать английский язык для достижения коммуникативных профессиональных целей будущими специалистами в сфере туризма. Результаты научного поиска доказывают, что в наше время были достигнуты значительные положительные результаты деятельности высших учебных заведений сферы туризма в обеих странах. Однако, существует несколько общих задач и проблем на образовательно-квалификационных уровнях «Бакалавр», «Магистр» в Украине и Турции. Как следствие, следующий вектор исследований в области туризма высшего образования может направляться на аудит и сертификацию учебных программ, пути обеспечения финансирования, а также установление сотрудничества между туристическими программами, отраслевыми партнерами и международными университетами.

Ключевые слова: профессиональное образование, туристическое образование, английский язык по профессиональному направлению, иноязычная коммуникативная компетентность, навыки, специалисты, приоритеты, стратегии, степени, программы.

Подано до редакиії 24.10.2016

Рецензент: Н. Б. Булгакова 